\title{
Pseudonocardia ammonioxydans sp. nov., isolated from coastal sediment
}

Correspondence

Shuang-Jiang Liu

shuangjiang@hotmail.com

\author{
Zhi-Pei Liu, Jian-Feng Wu, Zhi-Heng Liu and Shuang-Jiang Liu
}

State Key Laboratory of Microbial Resources at the Institute of Microbiology, Chinese Academy of Sciences, ZhongGuanCun, Haidian, Beijing 100080, PR China
The genus Pseudonocardia was first established by Henssen (1957) and its description has since been subjected to repeated emendations by Warwick et al. (1994), McVeigh et al. (1994), Reichert et al. (1998) and Huang et al. (2002). The current membership of the genus Pseudonocardia includes 16 species with validly published names that form a phylogenetically coherent cluster and exhibit physiological versatility: psychrotolerant (Prabahar et al., 2004), thermophilic (Henssen, 1957) and autotrophic and heterotrophic (Takamiya \& Tubaki, 1956). The physiological versatility of the species of Pseudonocardia renders them environmentally important in the removal of hazardous compounds and in biogeochemical cycles of elements. Pseudonocardia benzenivorans (Kämpfer \& Kroppenstedt, 2004) and Pseudonocardia chloroethenivorans (Lee et al., 2004) were enriched for degradation of 1,2,3,5-tetrachlorobenzene and trichloroethene, respectively. Pseudonocardia asaccharolytica and Pseudonocardia sufidoxydans were isolated from biofilters and they were reported to use dimethyl disulfide as an energy source (Reichert et al., 1998). In this paper, we describe the newly isolated actinomycete strain $\mathrm{H}^{\mathrm{T}}$.

Strain $\mathrm{H} 9^{\mathrm{T}}$ was isolated from coastal sediment $\left(20^{\circ} \mathrm{C}\right.$ and

Published online ahead of print on 21 October 2005 as DOI 10.1099/ ijs.0.63878-0.

The GenBank/EMBL/DDBJ accession number for the 16S rRNA gene sequence of strain $\mathrm{H}^{\top}$ is $\mathrm{AY} 500143$.

A figure showing an electron micrograph of strain $\mathrm{H} 9^{\top}$ and tables showing ammonia oxidation of nitrite and nitrate and cellular fatty acid composition of strain $\mathrm{H}^{\top}$ are available as supplementary material in IJSEM Online.
$3 \cdot 3 \%$ salinity of the overlying sea water, GPS location of sampling site was $120^{\circ} 14^{\prime} 12^{\prime \prime} \mathrm{E} 35^{\circ} 58^{\prime} 48^{\prime \prime} \mathrm{N}$ ) from JiaoDong peninsula near Tsingdao city, Shandong province, China, with a modified nitrifying medium [MNM; $2.0 \mathrm{~g}$ $\left(\mathrm{NH}_{4}\right)_{2} \mathrm{SO}_{4}, 0.25 \mathrm{~g} \mathrm{NaH}_{2} \mathrm{PO}_{4}, 0.75 \mathrm{~g} \mathrm{~K}_{2} \mathrm{HPO}_{4}, 0.01 \mathrm{~g}$ $\mathrm{MnSO}_{4} .4 \mathrm{H}_{2} \mathrm{O}, 0.03 \mathrm{~g} \mathrm{MgSO}_{4} .7 \mathrm{H}_{2} \mathrm{O}, 5.0 \mathrm{~g} \mathrm{CaCO}_{3}$ and $33 \mathrm{~g} \mathrm{NaCl}$ in $1000 \mathrm{ml}$ deionized water (pH 8.0)]. For preparation of silica plates, silica (GF 254; Tsingdao marine chemical factory) was used as the solid matrix and was washed with 5 vols deionized water. After being washed twice with deionized water and autoclaved, $30 \mathrm{ml}$ silica suspension $[50 \%(\mathrm{w} / \mathrm{v})$ in deionized water] was poured into each plate $\left(9 \mathrm{~cm}\right.$ in diameter) and dried at $50{ }^{\circ} \mathrm{C}$ for 5-7 days, and $4 \mathrm{ml}$ fivefold MNM was then added to the top of each plate and evaporated at $50{ }^{\circ} \mathrm{C}$. The plates were inoculated with a loopful of sediment sample $\left(0 \cdot 1 \mathrm{~g} \mathrm{ml}^{-1}\right.$, suspended in saline) and were incubated at $30^{\circ} \mathrm{C}$ for 1 month. One or two colonies were observed on each plate. Strain $\mathrm{H} 9^{\mathrm{T}}$ was purified after several transfers and streaking onto MNM silica plates. For the growth assay of strain $\mathrm{H} 9^{\mathrm{T}}$ in MNM, $20 \mathrm{ml}$ of the cultural liquid was sampled and centrifuged, and the supernatant was used for analysis of ammonium (Slawyk \& Maclsaac, 1972). The cell pellet was resuspended in $2 \mathrm{ml}$ sterile deionized water and cells were broken by sonication. Nitrite and nitrate were determined according to van't Riet et al. (1968) and Rand et al. (1975), respectively. Results indicated that strain $\mathrm{H}^{\mathrm{T}}$ grew autotrophically (uses $\mathrm{CaCO}_{3}$ as carbon source) and heterotrophically, and oxidized ammonia to nitrate in both MNM (nitrification) and blends of MNM and Luria-Bertani (LB) media (dissimilatory, heterotrophic ammonium oxidation; Supplementary Table S1 available in IJSEM Online). Strain 
$\mathrm{H} 9^{\mathrm{T}}$ showed typical morphology of the genus Pseudonocardia. Chains of spores formed by acropetal budding from branched substrate mycelium. Both substrate and aerial mycelia fragmented into rod-shaped elements on trypticase soy broth (TSB; BBL) agar. The diameter of the aerial mycelium was about $0 \cdot 5 \mu \mathrm{m}$ (Supplementary Fig. S1 available in IJSEM Online).

Physiological and biochemical tests were carried out by following the procedures of Gordon et al. (1974) and Reichert et al. (1998), respectively, using Biolog GP2 plates (MicroStation), with reference strains in parallel. Nitrate reduction test was carried out according to Dong \& Cai (2001). Strain $\mathrm{H}^{\mathrm{T}}$ grew at $\mathrm{NaCl}$ concentrations ranging from 0 to $8 \%$ with an optimum $\mathrm{NaCl}$ concentration of $3 \cdot 5 \%$. Detailed physiological and biochemical properties of strain $\mathrm{H} 9^{\mathrm{T}}$ are provided in the species description. Some characteristic and differential properties from phylogenetically closely related Pseudonocardia species are given in Table 1.

Cell-wall amino acids and whole-cell sugars were analysed by following the procedures developed by Hasegawa et al. (1983) and Lechevalier \& Lechevalier (1980). Strain $\mathrm{H}^{\mathrm{T}}$ contained meso-diaminopimelic acid and arabinose and galactose, thus giving a cell wall type IV, according to Lechevalier \& Lechevalier (1970, 1980). Cells of strain $\mathrm{H} 9^{\mathrm{T}}$ had type PIII phospholipid (Lechevalier et al., 1977; Lechevalier \& Lechevalier, 1980). No glucosamine-containing phospholipids were detected. Menaquinones were extracted and purified from freeze-dried biomass according to Collins (1985), and were determined by using an HPLC procedure (Wu et al., 1989). The major menaquinone of strain $\mathrm{H}^{\mathrm{T}}$ was MK-8 $\left(\mathrm{H}_{4}\right)$. Cellular fatty acids were determined as described previously (Hu et al., 2004). The results (Supplementary Table S2 available in IJSEM Online) indicated that the major fatty acids of strain $\mathrm{H}^{\mathrm{T}}$ were $16: 0(41 \cdot 1 \%)$, iso$16: 1(15 \cdot 7 \%)$ and $17: 1 \omega 8 c(12 \cdot 1 \%)$.

The 16S rRNA gene of strain $\mathrm{H} 9^{\mathrm{T}}$ was amplified and sequenced as described previously (Zhang et al., 2003), and the sequence was aligned by using the CLUSTAL X program (Thompson et al., 1997). The 16S rRNA gene sequence similarities of strain $\mathrm{H}^{\mathrm{T}}$ to members of the genus Pseudonocardia ranged from $93 \cdot 0$ to $97 \cdot 5 \%$. The closest relatives were Pseudonocardia kongjuensis $(97 \cdot 5 \%)$, Pseudonocardia autotrophica $(97 \cdot 1 \%)$ and Pseudonocardia compacta $(96 \cdot 8 \%)$, according to $16 \mathrm{~S}$ rRNA gene similarity. Phylogenetic trees were constructed with neighbour-joining and maximumparsimony methods, all trees showed similar topology. The tree constructed with the neighbour-joining method (Saitou \& Nei, 1987) using Kimura's two-parameter calculation model in TREECON $\mathrm{W}$ version $1.3 \mathrm{~b}$ (Van de Peer \& De Wachter, 1994) is shown in Fig. 1. Strain $\mathrm{H}^{\mathrm{T}}$, together with P. kongjuensis, P. autotrophica and P. compacta, formed a phyletic clade with $100 \%$ support.

DNA base composition was determined by thermal denaturation (Marmur \& Doty, 1962) and genomic DNA from Escherichia coli DH5 $\alpha$ was analysed in parallel for calibration
Table 1. Differential properties of strain $\mathrm{H} 9^{\top}$ from closely related Pseudonocardia species

Strains: 1, P. ammonioxydans $\mathrm{H} 9^{\mathrm{T}}$; 2, P. kongjuensis DSM $44525^{\mathrm{T}}$ (data from Prabahar et al., 2004); 3, P. autotrophica IMSNU $20050^{\mathrm{T}}$ (for columns 3-5, data from Lee et al., 2001); 4, P. compacta IMSNU $20111^{\mathrm{T}}$; 5, P. alni IMSNU 20049 ${ }^{\mathrm{T}}$; 6, P. antarctica DVS5a1 $^{\mathrm{T}}$ (data from Prabahar et al., 2004). +, Positive or present; W, weakly positive; -, negative or absent; ND, not done.

\begin{tabular}{|c|c|c|c|c|c|c|}
\hline Characteristic & 1 & 2 & 3 & 4 & 5 & 6 \\
\hline \multicolumn{7}{|l|}{ Acid production from: } \\
\hline L-Arabinose & + & - & + & - & + & - \\
\hline D-Cellobiose & - & + & + & + & - & - \\
\hline D-Galactose & + & + & + & - & + & + \\
\hline Maltose & + & + & + & - & + & + \\
\hline D-Mannose & + & + & + & - & - & + \\
\hline D-Melezitose & - & + & + & - & + & - \\
\hline Methyl $\alpha$-D-glucoside & - & - & + & - & - & ND \\
\hline Adonitol & + & + & + & - & + & - \\
\hline myo-Inositol & - & + & + & - & - & - \\
\hline 1,2-Propanediol & + & - & + & - & + & ND \\
\hline D-Sorbitol & - & - & + & - & + & - \\
\hline Sucrose & - & + & + & - & + & - \\
\hline D-Trehalose & + & + & + & - & + & - \\
\hline D-Xylose & $\mathrm{W}$ & + & + & - & + & + \\
\hline \multicolumn{7}{|l|}{ Decomposition of: } \\
\hline Hypoxanthine & - & + & - & - & + & + \\
\hline Tyrosine & + & + & - & - & + & + \\
\hline Xanthine & - & - & - & - & + & - \\
\hline \multicolumn{7}{|l|}{ Hydrolysis of: } \\
\hline Gelatin & $\mathrm{W}$ & - & - & - & + & ND \\
\hline Starch & $\mathrm{W}$ & - & - & - & + & + \\
\hline Casein & + & + & - & - & - & - \\
\hline Urease activity & + & + & + & - & + & + \\
\hline $\mathrm{NO}_{3}^{-}$reduction to $\mathrm{NO}_{2}^{-}$ & + & - & - & + & - & + \\
\hline $\mathrm{H}_{2} \mathrm{~S}$ production & + & + & + & - & + & ND \\
\hline Oxidation of ammonia & + & - & - & + & - & - \\
\hline \multicolumn{7}{|l|}{ Growth at/on: } \\
\hline $4{ }^{\circ} \mathrm{C}$ & + & + & - & + & - & - \\
\hline $37^{\circ} \mathrm{C}$ & + & + & + & - & + & + \\
\hline $7 \% \mathrm{NaCl}$ & + & + & + & - & + & + \\
\hline
\end{tabular}

of the $T_{\mathrm{m}}$ value. The result showed that the $\mathrm{G}+\mathrm{C}$ content of strain $\mathrm{H}^{\mathrm{T}}$ was $69 \cdot 6 \mathrm{~mol} \%\left(T_{\mathrm{m}}\right)$. DNA-DNA hybridizations were carried out according to De Ley et al. (1970). Renaturation rates and relatedness values were calculated as described by Jahnke (1992). DNA-DNA relatedness values between strain $\mathrm{H}^{\mathrm{T}}$ and $P$. kongjuensis DSM $44525^{\mathrm{T}}, P$. autotrophica IMSNU $20050^{\mathrm{T}}$ and $P$. compacta IMSNU $20111^{\mathrm{T}}$ were 42,13 and $11 \%$, respectively.

\section{Description of Pseudonocardia ammonioxydans sp. nov.}

Pseudonocardia ammonioxydans (N.L. n. ammonia ammonia; N.L. part. adj. oxydans oxidizing; N.L. part. adj. ammonioxydans oxidizing ammonia). 


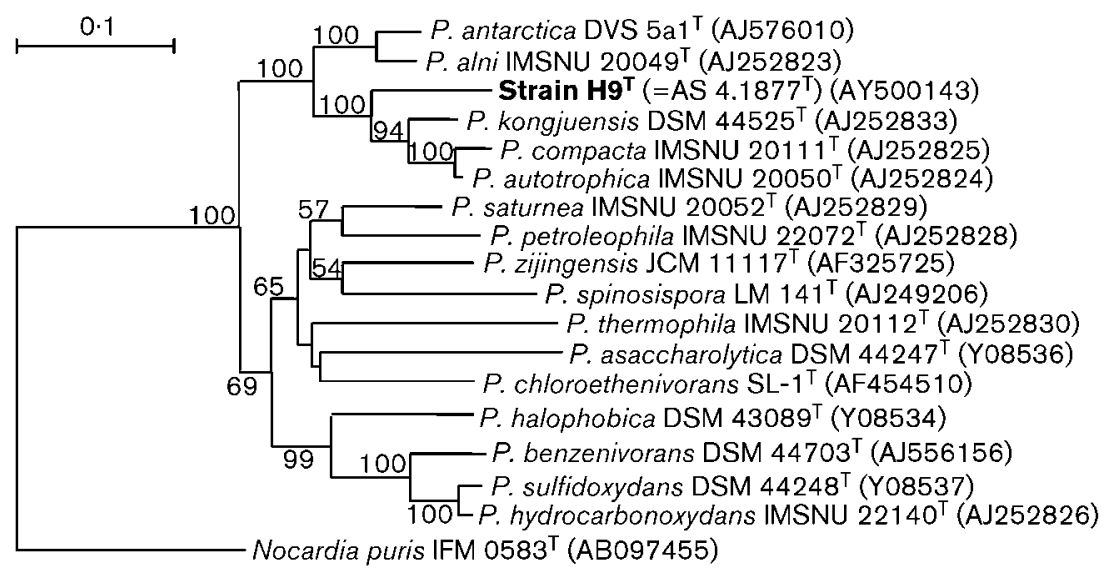

Fig. 1. Neighbour-joining phylogenetic tree based on 16S rRNA gene sequences showing the position of strain $\mathrm{H}^{\top}$ in the genus Pseudonocardia. Numbers at nodes indicate percentages of bootstrap support based on a neighbour-joining analysis of 1000 resampled datasets; only values over $50 \%$ are shown. Norcardia puris IFM $0583^{\top}$ was used as the outgroup. Bar, evolutionary distance $\left(K_{\text {nuc }}\right)$ of $0 \cdot 1$.

Aerobic, Gram-positive. Forms branched, brown substrate mycelium and white aerial mycelium on TSB and LB agar. The mycelium fragments into rod-shaped elements. Smooth spores are borne in short chains by acropetal budding from the substrate mycelium. No pigment is produced. Growth occurs at $10-40{ }^{\circ} \mathrm{C}$. Growth occurs on MNM and ammonia is oxidized to nitrate as the sole energy source. Ammonia is also oxidized to nitrate during growth on a blend of MNM and $\mathrm{LB}$ media. Growth occurs at $\mathrm{NaCl}$ concentrations ranging from 0 to $8 \%$ with an optimum at $3.5 \% \mathrm{NaCl}$. Catalasepositive. Acid is produced from D-fructose, D-glucose, $\mathrm{N}$ acetyl-D-glucosamine, D-ribose, D-arabitol, D-galacturonic acid, D-gluconic acid and glycerol, but not from $\mathrm{N}$-acetyl$\beta$-D-mannosamine, arbutin, L-fucose, gentiobiose, $\alpha$-Dlactose, lactulose, maltotriose, methyl $\alpha$-D-galactoside, methyl $\beta$-D-galactoside, methyl $\alpha$-D-glucoside, methyl $\alpha$ D-mannoside, palatinose, D-psicose, D-raffinose, L-rhamnose, D-gagatose, turanose or xylitol. Uses acetic acid, $\beta$ hydroxybutyric acid, $\alpha$-ketoglutaric acid, lactamide, D-lactic acid methyl ester, L-lactic acid, L-malic acid, pyruvic acid methyl ester, succinic acid mono-methyl ester, propionic acid, succinamic acid, succinic acid, $\mathrm{N}$-acetyl-L-glutamic acid, L-alaninamide, D-alanine, L-alanine, L-alanyl glycine, L-asparagine, L-glutamic acid, glycyl L-glutamic acid, Lpyroglutamic acid, L-serine, putrescine, but not $\alpha$-hydroxybutyric acid, $\gamma$-hydroxybutyric acid, $p$-hydroxyphenylacetic acid, $\alpha$-ketovaleric acid, D-malic acid or pyruvic acid. Other physiological properties are listed in Table 1. The cellwall chemotype is type IV. Predominant menaquinone is MK-8 $\left(\mathrm{H}_{4}\right)$. It contains phosphatidylcholine, phosphatidylglycerol, phosphatidylmethylethanolamine, phosphatidylinositol mannosides and diphosphatidylglycerol, but does not contain glucosamine-containing phospholipids or mycolic acids. The major fatty acids are iso-hexadecanoic acid (16:0-iso, $41 \cdot 1 \%)$, iso-hexadecenoic acid (16:1-iso, $15 \cdot 7 \%)$ and heptadecenoic acid $(17: 1 \omega 8 c, 12 \cdot 1 \%)$. The $\mathrm{G}+\mathrm{C}$ content of the DNA is $69 \cdot 6 \mathrm{~mol} \%\left(T_{\mathrm{m}}\right)$.

The type strain, $\mathrm{H}^{\mathrm{T}}\left(=\mathrm{CGMCC} 4.1877^{\mathrm{T}}=\mathrm{JCM} 12462^{\mathrm{T}}\right)$, was isolated from coastal sediment collected from JiaoDong peninsula near Qingdao, Shandong province, China.

\section{Acknowledgements}

This work was supported by projects from the Chinese National Natural Science Foundation (30470024) and from the State Key Laboratory of Marine Ecology and Environmental Science at the Institute of Oceanology (Tsingdao), Chinese Academy of Sciences.

\section{References}

Collins, M. D. (1985). Isoprenoid quinone analysis in classification and identification. In Chemical Methods in Bacterial Systematics, pp. 267-287. Edited by M. Goodfellow \& D. E. Minnikin. London: Academic Press.

De Ley, J., Cattoir, H. \& Reynaerts, A. (1970). The quantitative measurement of DNA hybridization from renaturation rates. Eur $J$ Biochem 12, 133-142.

Dong, X.-Z. \& Cai, M.-Y. (2001). Determinative Manual for Routine Bacteriology. Beijing: Scientific Press (English translation).

Gordon, R. E., Barnett, D. A., Handerhan, J. E. \& Pang, C. H.-N. (1974). Norcardia coeliaca, Nocardia autotrophica, and the nocardin strain. Int J Syst Bacteriol 24, 54-63.

Hasegawa, T., Takizawa, M. \& Tanida, S. (1983). A rapid analysis for chemical grouping of aerobic actinomycetes. J Gen Appl Microbiol 29, 319-322.

Henssen, A. (1957). Beiträge zur morphologie und systematik der thermophilen actinomyceten. Arch Mikrobiol 26, 373-414 (in German).

Hu, Y.-T., Zhou, P.-J., Zhou, Y.-G., Liu, Z.-H. \& Liu, S.-J. (2004). Saccharothrix xingjiangensis, sp. nov., a pyrene-degrading actinomycete isolated from Tianchi Lake, Xinjiang, China. Int J Syst Evol Microbiol 54, 2091-2094.

Huang, Y., Wang, L., Lu, Z., Hong, L., Liu, Z., Tan, G. Y. A. \& Goodfellow, M. (2002). Proposal to combine the genera Actinobispora and Pseudonocardia in an emended genus Pseudonocardia, and description of Pseudonocardia zijingensis sp. nov. Int J Syst Evol Microbiol 52, 977-982.

Jahnke, K.-D. (1992). Basic computer program for evaluation of spectroscopic DNA renaturation data from GILFORD System 2600 spectrometer on a PC/XT/AT type personal computer. J Microbiol Methods 15, 61-73.

Kämpfer, P. \& Kroppenstedt, R. (2004). Pseudonocardia benzenivorans sp. nov. Int J Syst Evol Microbiol 54, 749-751.

Lechevalier, M. P. \& Lechevalier, H. A. (1970). Chemical composition as a criterion in the classification of aerobic actinomycetes. Int J Syst Bacteriol 20, 435-443. 
Lechevalier, H. A. \& Lechevalier, M. P. (1980). The chemotaxonomy of actinomycetes. In Actinomycete Taxonomy, Special Publication no. 6, pp. 277-284. Edited by A. Dietz \& D. W. Thayer. Arlington, VA: Society for Industrial Microbiology.

Lechevalier, M. P., De Bièvre, C. \& Lechevalier, H. A. (1977), Chemotaxonomy of aerobic actinomycetes: phospholipid composition. Biochem Syst Ecol 5, 249-260.

Lee, S. D., Kim, E. S., Min, K.-L., Lee, W. Y., Kang, S.-O. \& Hah, Y. C. (2001). Pseudonocardia kongjuensis sp. nov., isolated from a gold mine cave. Int J Syst Evol Microbiol 51, 1505-1510.

Lee, S.-B., Strand, S. E., Stensel, H. D. \& Herwig, R. P. (2004). Pseudonocardia chloroethenivorans sp. nov., a chloroethene-degrading actinomycete. Int J Syst Evol Microbiol 54, 131-139.

Marmur, J. \& Doty, P. (1962). Determination of the base composition of deoxyribonucleic acid from its thermal denaturation temperature. J Mol Biol 5, 109-118.

McVeigh, H. P., Munro, J. \& Embley, T. M. (1994). The phylogenetic position of Pseudoamycolata halophobica (Akimov et al. 1989) and a proposal to reclassify it as Pseudonocardia halophobica. Int J Syst Bacteriol 44, 300-302.

Prabahar, V., Dube, S., Reddy, G. S. N. \& Shivaji, S. (2004). Pseudonocardia antarctica sp. nov., an Actinomycetes from McMurdo Dry Valleys, Antarctica. Syst Appl Microbiol 27, 66-71.

Rand, M. C., Greenberg, A. E. \& Taras, M. J. (editors) (1975). Standard Methods for the Examination of Water and Wastewater, 14th edn, pp. 434-436. Washington, DC: American Public Health Association.

Reichert, K., Lipski, A., Pradella, S., Stackebrandt, E. \& Altendorf, K. (1998). Pseudonocardia asacccharolytica sp. nov. and Pseudonocardia sulfidoxydans sp. nov., two new dimethyl disulfide-degrading actinomycetes and emended description of the genus Pseudonocardia. Int J Syst Bacteriol 48, 441-449.
Saitou, N. \& Nei, M. (1987). The neighbor-joining method: a new method for reconstructing phylogenetic trees. Mol Biol Evol 4, 406-425.

Slawyk, G. \& Maclsaac, J. J. (1972). Comparison of two automated ammonium methods in a region of coastal upwelling. Deep Sea Res 19, 521-524.

Takamiya, A. \& Tubaki, K. (1956). A new form of Streptomyces capable of growing autotrophically. Arch Mikrobiol 25, 58-64.

Thompson, J. D., Gibson, T. J., Plewniak, F., Jeanmougin, F. \& Higgins, D. G. (1997). The CLUSTAL $\mathrm{X}$ windows interface: flexible strategies for multiple sequence alignment aided by quality analysis tools. Nucleic Acids Res 25, 4876-4882.

Van de Peer, Y. \& De Wachter, R. (1994). TREECON for Windows: a software package for the construction and drawing of evolutionary trees for the Microsoft Windows environment. Comput Appl Biosci 10, 569-570.

van't Riet, J., Stouthamer, A. H. \& Planta, R. J. (1968). Regulation of nitrate assimilation and nitrate respiration in Aerobacter aerogenes. J Bacteriol 96, 1455-1464.

Warwick, S., Bowen, T., McVeigh, H. P. \& Embley, T. M. (1994). A phylogenetic analysis of the family Pseudonocardiaceae and the genera Actinokineospora and Saccharothrix with 16S rRNA sequences and a proposal to combine the genera Amycolata and Pseudonocardia in an emended genus Pseudonocardia. Int J Syst Bacteriol 44, 293-299.

Wu, C., Lu, X., Qin, M., Wang, Y. \& Ruan, J. (1989). Analysis of menaquinone compound in microbial cells by HPLC. Microbiology (English translation of Mikrobiologiia) 16, 176-178.

Zhang, D., Yang, H., Zhang, W., Huang, Z. \& Liu, S.-J. (2003). Rhodocista pekingensis sp. nov., a cyst-forming phototrophic bacterium from a municipal wastewater treatment plant. Int J Syst Evol Microbiol 53, 1111-1114. 